\title{
Postharvest quality, antioxidant activity and acceptability of strawberries grown in conventional and organic systems
}

\author{
Qualidade pós-colheita, atividade antioxidante e aceitabilidade de morangos \\ cultivados em sistemas convencional e orgânico
}

\section{Allan Ricardo Domingues ${ }^{1 *}$, Thais Cristina Morais Vidal', Fernando Teruhiko Hata1, Maurício Ursi Ventura1, Leandro Simões Azeredo Gonçalves' ${ }^{1}$, Josemeyre Bonifácio da Silva' ${ }^{1}$}

'Universidade Estadual de Londrina (UEL), Centro de Ciências Agrárias (CCA), Departamento de Agronomia, Londrina/PR - Brasil

\section{${ }^{*}$ Corresponding Author}

Allan Ricardo Domingues, Universidade Estadual de Londrina (UEL), Departamento de Agronomia, Campus Universitário, Rodovia Celso Garcia Cid, PR 445, km 380, Jd. Perobal, CP 10011, CEP: 86057-970, Londrina/PR - Brasil, e-mail: allandomingez@hotmail.com

Cite as: Postharvest quality, antioxidant activity and acceptability of strawberries grown in conventional and organic systems. Braz. J. Food Technol., v. 21, e2017154, 2018.

\section{Abstract}

The aim of this study was to evaluate the influence of organic and conventional cultivation systems and the cultivars on the postharvest quality, antioxidant activity and acceptability of strawberries. Strawberries of the cultivars Albion, Monterey and San Andreas were analysed with respect to the soluble solids content (SS), titratable acidity (TA), SS/TA ratio, fruit colour, vitamin $\mathrm{C}$ content, antioxidant activity by the DDPH method, mineral composition and acceptability. The cultivation systems and cultivars had different influences on the SS, TA, pH, SS/TA and colour of the strawberries. The vitamin $\mathrm{C}$ content of $\mathrm{cv}$. Monterey was higher (78.68 $\mathrm{mg}$ ascorbic acid $100 \mathrm{~g}^{-1}$ ) than that of cv. San Andreas (70.28 mg ascorbic acid $100 \mathrm{~g}^{-1}$ ) in the conventional system, while in the organic system, the cultivars did not differ. Differences were not observed amongst the cultivars and cultivation conditions for antioxidant activity and the cultivation systems and cultivars had no effect on the $\mathrm{P}, \mathrm{Cu}$ and $\mathrm{Mg}$ mineral contents. The conventionally cultivated strawberries of $\mathrm{cv}$. Monterey obtained the highest value for acceptance (7.51) while the organically cultivated strawberries of cv. San Andreas received the lowest value (6.58).

Keywords: Fragaria x ananassa; Vitamin C; Mineral composition; DPPH method; Soluble solids.

\section{Resumo}

O objetivo deste estudo foi avaliar a influência dos sistemas de cultivo, orgânico e convencional, e também de cultivares sobre a qualidade pós-colheita, atividade antioxidante e aceitabilidade de frutos de morango. Os frutos das cultivares Albion, Monterey e San Andreas foram analisados em relação ao teor de sólidos solúveis (SS), acidez titulável (AT), relação SS/AT, coloração dos frutos, teor de vitamina $\mathrm{C}$, atividade antioxidante, composição mineral e aceitabilidade dos frutos de morango das cultivares Albion, Monterey e San Andreas. Os sistemas de cultivo e cultivares influenciaram o teor de SS, AT, pH, relação SS/AT e coloração dos frutos. O teor da vitamina C dos frutos da cv. Monterey foi superior (78,68 mg ácido ascórbico $\left.100 \mathrm{~g}^{-1}\right)$ ao teor da cv. San Andreas (70,28 mg ácido ascórbico $\left.100 \mathrm{~g} \mathrm{~g}^{-1}\right)$ no sistema convencional, ao passo que no sistema orgânico, as cultivares não diferiram entre si. Além disso, não foram observadas diferenças entre as cultivares e sistemas de cultivo para a atividade antioxidante. Com relação aos sistemas de cultivo e as cultivares, os mesmos não tiveram efeito sobre o teor dos minerais P, Cu e Mg. Os frutos de morango da cv. Monterey no sistema convencional obtiveram melhores valores de aceitação $(7,51)$, diferente do observado para a cv. San Andreas no sistema orgânico com valores menos aceitos pelos consumidores $(6,58)$.

Palavras-chave: Fragaria x ananassa; Vitamina C; Composição mineral; Método de DPPH; Sólidos solúveis. 


\section{Introduction}

The growing concerns of consumers regarding food quality require the determination of food composition and its nutritional value (MANDAVE et al., 2014), particularly with regard to antioxidants and their ability to reduce the damaging effects of cell oxidation caused by free radicals (SEN; CHAKRABORTY, 2011; GUNDUZ; OZDEMIR, 2014). Antioxidant activity has been attributed to the presence of different phytochemical compounds such as phenolic acids, flavonoids, carotenoids, ascorbic acid and anthocyanins (MALIK; MUKHTAR, 2006).

Strawberries (Fragaria x ananassa, Rosaceae) are considered important sources of bioactive compounds, with antioxidant activity (YANG et al., 2016) due to the presence of flavonoids, such as anthocyanins, hydrolysable tannins and phenolic compounds, as well as ascorbic acid (vitamin C), pigments and folate (CEREZO et al., 2010).

The chemical composition and functional quality of the strawberry can be influenced by many pre-harvest factors such as the genotype, climate, cultivation system, maturity and luminosity (AABY et al., 2012; FERNANDES et al., 2012; PINCEMAIL et al., 2012.). Antunes et al. (2014) found significant differences in the soluble solids content, acidity, ascorbic acid and mineral contents in different strawberry genotypes in two seasons. Aaby et al. (2012) determined the concentrations of phenolic compounds in 27 strawberry cultivars during maturation, and found values ranging

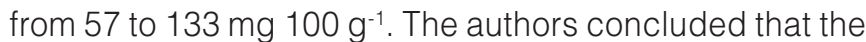
anthocyanins were slightly affected by the ripening stage and growing conditions. Pincemail et al. (2012) observed that the timing of the strawberry harvest had a greater influence on the antioxidant capacity than the genotype. On the other hand, Gunduz and Ozdemir (2014) observed that the genotype had a greater effect than the environment on the antioxidants of strawberries, and therefore breeding programs aimed at selecting varieties with high bioactive contents could be successful.

There is little information concerning the influence of cultivation systems (conventional or organic) on the sensory attributes and chemical composition of strawberries. Some studies state that organic fruits show higher ascorbic acid contents, anthocyanins, flavonoids and phenolic compounds than those produced in the conventional system (YOU et al., 2011; FERNANDES et al., 2012). Fernandes et al. (2012) reported that organically cultivated strawberries showed higher total phenolic contents than those cultivated in the integrated pest management system (IPM). The authors also found higher antioxidant activity, as determined by the DDPH (2,2-Dyphenil-1-picrylhydrazyl) and FRAP (Ferric Reducing Antioxidant Power) methods, in fruits cultivated in the organic system.
Other studies reported there was insufficient evidence to conclude that organic foods had greater nutritional qualities than foods produced in the conventional system (WINTER; DAVIS, 2006; LAIRON, 2010). Luthria et al. (2010), working with eggplant, found no differences between the organic and conventional cultivation systems with respect to the phenolic compound content. The authors suggested that more research was needed on the subject. Thus the aim of this study was to evaluate the influence of the organic and conventional cultivation systems and the cultivars on the postharvest quality, antioxidant activity and acceptability of strawberries.

\section{Materials and methods}

The strawberry cultivars evaluated were: Albion, San Andreas and Monterey. The fruits were acquired from four commercial crops, harvested in 2015 from the Marialva region, Paraná, Brazil. Two of these crops came from the conventional cultivation system and two from the organic cultivation system. The fruits were randomly collected from 40 plants of each genotype at the commercial maturity point, when $75 \%$ of the fruit surface was red in colour.

One part of the strawberries collected was frozen at $-90{ }^{\circ} \mathrm{C}$, freeze-dried (Christ Lyophilizer, model 500) and ground in a knife grinder (100 mesh) (Mill IKA Model A1) for the analysis of antioxidants, vitamin $\mathrm{C}$ and mineral content. A subsample was maintained fresh and refrigerated at $4{ }^{\circ} \mathrm{C}$ for the analysis of soluble solids (SS), titratable acidity (TA), ratio (SS/TA), $\mathrm{pH}$, colour and acceptability.

\subsection{Analysis of the fresh fruits}

\subsubsection{Soluble Solids (SS)}

The soluble solids content was determined using a refractometer $\left(\right.$ Atago $\left.^{\circledR}\right)$. The results reported were the average of three replicates, expressed in ${ }^{\circ} \mathrm{Brix}$ (IAL, 2008).

\subsubsection{Titratable Acidity (TA)}

The titratable acidity was determined by diluting $10 \mathrm{~g}$ of fresh strawberries in $100 \mathrm{~mL}$ of distilled water, and titrating the solution to $\mathrm{pH} 8.1$ with $0.1 \mathrm{M} \mathrm{NaOH}$. The results reported were the average of three replicates, expressed as the percentage of citric acid (\% citric acid) (IAL, 2008).

\subsubsection{Ratio of total Soluble Solids (SS) to Titratable Acidity (TA)}

The SS/TA ratio reported was the average of three replicates, calculated as the ratio of the total soluble solids content to the titratable acidity. 


\subsection{4 pH}

The $\mathrm{pH}$ was measured using a potentiometer and reported as the average of three replicates (Quimis, Q.400.A) (IAL, 2008).

\subsubsection{Colour parameters}

The colour parameters of the fruits such as lightness $\left(L^{*}\right)$, which indicates luminosity, ranging from 0 (black) to 100 (white), the red-green component $\left(a^{*}\right)$, which indicates red $(+)$ and green $(-)$, and the yellow-blue component $\left(b^{*}\right)$, which indicates yellow (+) and blue (-), were determined using a colorimeter (Minolta Japan Co., model CR-13) with an observer angle of $10^{\circ}$ and the D65 illuminant (CANER; ADAY, 2008).

\subsubsection{Acceptability test}

The acceptability of the strawberries was evaluated in the laboratory of the Agronomy Department (Centro de Ciências Agrárias, Universidade Estadual de Londrina, Londrina, Paraná, Brazil) with 100 consumers. The consumers filled in a questionnaire about their fruit consumption frequency, fruit of choice, and socio-demographic data including age, gender and level of education. The consumers were then requested to evaluate the samples. The samples were served at room temperature $\left(25^{\circ} \mathrm{C}\right)$ in $50 \mathrm{~mL}$ plastic cups, with strawberries from each treatment, coded with three-digit numbers. The presentation order was randomized for each consumer (STONE; SIDEL, 2004) and a nine-point hedonic scale used to evaluate acceptance as follows: ( 1 = disliked extremely; 2 = disliked a lot; $3=$ disliked moderately; $4=$ disliked slightly; $5=$ neither liked/nor disliked; $6=$ liked slightly; $7=$ liked moderately; $8=$ liked a lot, $9=$ liked extremely) (FERREIRA et al., 2000). The purchase intention of the participants in relation to the strawberries was evaluated using a three-point scale, where: 1 = yes; 2 = no and 3 = perhaps (MEILGAARD et al., 1999). Mineral water at room temperature was available for consumers to clean their palates between samples.

\subsection{Analyses of the freeze-dried fruits}

\subsubsection{Vitamin C}

The vitamin $\mathrm{C}$ content was determined using the Tillmans method (IAL, 2008). A $10 \mathrm{~g}$ sample of freeze-dried strawberry, $50 \mathrm{~mL}$ of distilled water and $50 \mathrm{~mL}$ of $1 \%$ oxalic acid was titrated with 2,6-dichlorophenol indophenol to a persistent pink colour. The results, presented as the average of three replicates, were expressed in mg ascorbic acid $100 \mathrm{~g}^{-1}$.

\subsubsection{Antioxidant activity}

The antioxidant activity was determined according to Aruoma (2003), Brand-Williams et al. (1995) and Sorrenti et al. (2006), with some modifications. For extraction, $1 \mathrm{~g}$ of freeze-dried strawberry sample was placed in a Falcon centrifuge tube $(50 \mathrm{~mL})$ and $20 \mathrm{~mL}$ of $50 \%$ methanol added. The samples were allowed to stand for $30 \mathrm{~min}$ at room temperature $\left(25^{\circ} \mathrm{C}\right)$ and then centrifuged (Centrilab, TDZ5) at 25000 rpm for $5 \mathrm{~min}$, transferring the supernatant to fresh tubes containing $20 \mathrm{~mL}$ of $70 \%$ acetone. The residues were homogenized again, allowed to stand for $30 \mathrm{~min}$ at room temperature and centrifuged under the same conditions described above. The supernatant was used for analysis. Aliquots of $0.1 \mathrm{~mL}$ of each extract dilution were transferred to test tubes containing $3.9 \mathrm{~mL}$ of 2,2- diphenyl-1-picrylhydrazyl radical (0.06 mM DPPH). Methanol and DPPH were used as the controls, using methanol to calibrate the spectrophotometer (Micronal, AJX-1600). Readings were obtained at $515 \mathrm{~nm}$ after $30 \mathrm{~min}$. The percent decrease in absorbance was recorded for each sample, and the percent inhibition of the DPPH radical calculated on the basis of the observed decrease in absorbance according to the following formula: \% Inhibtion $=\left[\left(A_{0}-A_{1}\right) / A_{0}\right] \times 100$. Where $A_{0}$ is the absorbance of the DPPH blank solution and $A_{1}$ the absorbance of the sample solution. The results reported were averages of three replicates, expressed as $\%$ (percent) inhibition.

\subsubsection{Mineral composition}

The macronutrient ( $\mathrm{Ca}, \mathrm{K}, \mathrm{P}, \mathrm{Mg}$ ) and micronutrient ( $\mathrm{Cu}, \mathrm{Mn}, \mathrm{Fe}$ ) contents were determined according to Malavolta (1997): the samples were treated with a mixture of concentrated nitric and perchloric acids at high temperature. The macro and micronutrients were dissolved, subjected to different treatments and diluted for further quantitative evaluation. The nutrients were quantified by spectrophotometry using a standard curve for each mineral. Atomic absorption spectrophotometry (Model GBC 932 AA, Australia) was used to determine the calcium, magnesium, copper, iron and manganese concentrations. A flame photometer was used to determine potassium $(768 \mathrm{~nm}$ ) and a visible-light spectrophotometer to determine phosphorus (420 nm). The results reported were averages of three replicates, expressed in $\mathrm{g} \mathrm{kg}^{-1}$ for macronutrients and $\mathrm{mg} \mathrm{kg}^{-1}$ for micronutrients.

\subsection{Statistical analysis}

A $3 \times 2$ factorial experimental design was used to determine the chemical analyses, with 3 strawberry cultivars (Albion, San Andreas and Monterey) and 2 cultivation systems (organic and conventional), totalling 6 treatments with three replicates of each. The results were evaluated using an analysis of variance (ANOVA), and the treatment means compared by Tukey's test at $5 \%$ probability using Sisvar software (FERREIRA, 2003).

A randomized complete block experimental design was used to determine acceptance. The data were subjected to an analysis of variance (ANOVA) with 
two sources of variation (strawberries and consumers). The acceptance means were compared by Tukey's test at a significance level of $5 \%$. The results obtained for the socio-demographic profiles and purchase intentions were presented as percentages (\%) of the responses. Version 8.2 of SAS (SAS. Inst. Inc. Cary. N.C. U.S.A) was used to carry out the statistical analyses.

\section{Results and discussion}

\subsection{Soluble Solids (SS), Titratable Acidity (TA), pH and Ratio (SS/TA)}

The soluble solids contents (SS) of the three fruit cultivars, cultivated in the conventional system did not differ from each other; however, when cultivated in the organic system, the $\mathrm{cv}$. Albion showed the highest value $\left(9.90^{\circ} \mathrm{Brix}\right)$ and $\mathrm{cv}$. San Andreas the lowest value ( $\left.7.87^{\circ} \mathrm{Brix}\right)$. The SS content was higher in the organic system than in the conventional for Albion and Monterey but did not differ for San Andreas (Table 1).

The cv. Monterey strawberries showed the lowest acidity $(0.62 \%$ citric acid) when cultivated in the conventional system, but did not differ from the other cultivars when cultivated in the organic system. With regards to $\mathrm{pH}$, the cultivars showed no differences when cultivated in the conventional system, but when cultivated in the organic system, the Monterey cultivar showed the lowest value (2.79) (Table 1). Ávila et al. (2012) evaluated the influence of conventional and organic cultivation on the physicochemical characteristics of strawberries, and found that the titratable acid content ranged from $50 \%$ to $99 \%$ and the SS/TA ratio from 5.38 to 13.18. These values are within the ranges of those found in the present study. Differences were not observed between the two cultivation systems.
The soluble solids content is an important quality indicator for fruits (ADAY et al., 2013) to assess the indirect amount of sugars present. Organic acids are present in lower levels in strawberries but are also important because they contribute to the flavour and sensory quality of the fruit. Antunes et al. (2014), studying the cultivars San Andreas, Monterey and Albion, recorded a variation of 5.11 to $6.95{ }^{\circ}$ Brix for SS, 0.99 to $1.51 \mathrm{mg}$ of citric acid $100 \mathrm{~g}^{-1}$ for acidity and 3.53 to 7.29 for the SS/TA ratio.

\subsection{Vitamin C content and antioxidant activity}

The vitamin $\mathrm{C}$ content of $\mathrm{cv}$. Monterey was higher (78.68 $\mathrm{mg}$ ascorbic acid $100 \mathrm{~g}^{-1}$ ) than cv. San Andreas (70.28 mg ascorbic acid $100 \mathrm{~g}^{-1}$ ) in the conventional system (Table 1), but did not differ in the organic system. For cv. Albion, no difference was seen between the conventional and organic systems. The vitamin $\mathrm{C}$ content is one of the most important nutritional quality factors and can be influenced by genotype, climatic conditions, cultural practices, maturation and harvesting (LEE; KADER, 2000). When studying the Albion, San Andreas and Monterey strawberry cultivars in two planting seasons, Antunes et al. (2014) found contents between 49.76 and $113.12 \mathrm{mg}$ of ascorbic acid $100 \mathrm{~g}^{-1}$. Souza et al. (2014) found an ascorbic acid

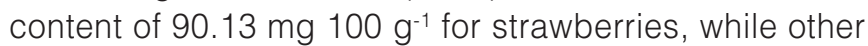
authors found values ranging from 32 to $85 \mathrm{mg}^{100 \mathrm{~g}^{-1}}$ (HAKALA et al., 2003; PANTELIDIS et al., 2007).

With respect to the antioxidant activity determined by the DPPH method, no differences were found amongst the strawberry cultivars or between the conventional and organic systems (Table 1). Gunduz and Ozdemir (2014) studied the influence of genotype and environmental conditions on the antioxidant activity of strawberries,

Table 1. Soluble Solids (SS), Titratable Acidity (TA), pH value, ratio SS/TA, vitamin C content and antioxidant activity of strawberry cultivars cultivated in the organic $(\mathrm{O})$ and conventional $(\mathrm{C})$ systems.

\begin{tabular}{|c|c|c|c|c|c|}
\hline Chemical characteristics & Cultivation & Albion & Monterey & San Andreas & CV (\%) \\
\hline Soluble solids & C & $8.27 \mathrm{Ab}^{1}$ & $8.03 \mathrm{Ab}$ & $6.97 \mathrm{Aa}$ & \multirow{2}{*}{9.14} \\
\hline ( ${ }^{\circ}$ Brix) & O & $9.90 \mathrm{Aa}$ & $9.43 \mathrm{ABa}$ & $7.87 \mathrm{Ba}$ & \\
\hline Titratable acidity & C & $0.81 \mathrm{Aa}$ & $0.62 \mathrm{Bb}$ & $0.84 \mathrm{Aa}$ & \multirow{2}{*}{7.60} \\
\hline (\% citric acid) & O & $0.90 \mathrm{Aa}$ & $0.80 \mathrm{Aa}$ & $0.87 \mathrm{Aa}$ & \\
\hline \multirow{2}{*}{$\mathrm{pH}$ value } & C & 3.36 Aa & $3.19 \mathrm{Aa}$ & $3.09 \mathrm{Aa}$ & \multirow{2}{*}{4.61} \\
\hline & 0 & $3.06 \mathrm{ABb}$ & $2.79 \mathrm{Bb}$ & $3.18 \mathrm{Aa}$ & \\
\hline \multirow{2}{*}{ Ratio (SS/AT) } & C & 10.20 Aba & $12.87 \mathrm{Aa}$ & 8.37 Ba & \multirow{2}{*}{13.70} \\
\hline & 0 & $11,17 \mathrm{Aa}$ & $11,80 \mathrm{Aa}$ & $9,10 \mathrm{Aa}$ & \\
\hline Vitamin C & $\mathrm{C}$ & $75.32 \mathrm{ABa}$ & $78.68 \mathrm{Aa}$ & $70.28 \mathrm{Bb}$ & \multirow{2}{*}{4.82} \\
\hline$\left(\mathrm{mg}\right.$ ascorbic acid $\left.100 \mathrm{~g}^{-1}\right)$ & 0 & $75.01 \mathrm{Aa}$ & $70.12 \mathrm{Ab}$ & $77.46 \mathrm{Aa}$ & \\
\hline Antioxidant activity & C & 47.87 Aa & $40.20 \mathrm{Aa}$ & $48.93 \mathrm{Aa}$ & \multirow{2}{*}{27.66} \\
\hline (\% inhibition) & O & $45.77 \mathrm{Aa}$ & $39.07 \mathrm{Aa}$ & $46.57 \mathrm{Aa}$ & \\
\hline
\end{tabular}

${ }^{1}$ Means followed by the same letters, uppercase in the lines and lowercase in the columns, do not differ according to Tukey's test at $5 \%$ probability. 
and reported that the effect of genotype was greater than that of the cultivation conditions. In another study, the antioxidant activity of the strawberry cultivars Tudla and Maletto, as determined by the DPPH method, showed values for $\%$ inhibition of $41.8 \%$ and $78.24 \%$, respectively (PANICO et al., 2009). Fernandes et al. (2012) studied various strawberry genotypes and reported differences in antioxidant capacity between those cultivated in an organic system and those cultivated in an IPM system.

Several methods can be used to evaluate the antioxidant capacity, such as the DPPH method, the $\beta$-carotene/linoleic acid co-oxidation method, and the ABTS and FRAP methods. The DPPH method is based on measuring the antioxidant capacity of a substance to remove the DPPH radical by reducing it to hydrazine. When a substance that acts as a hydrogen atom donor is added to a DPPH solution, hydrazine is obtained, with a simultaneous change in colour from violet to pale yellow. Due to the various types of radical and different oxidation targets, no single method is capable of safely and accurately representing the exact antioxidant activity of a compound (ALVES et al., 2010) and therefore differences in antioxidant capacity can be found in the literature.

\subsection{Colour parameters}

Strawberries of the cultivar Monterey cultivated in the conventional system, presented the lowest values for the brightness parameter $\left(L^{*}\right)$ (Table 2$)$, indicating that these fruits were darker than those of the other cultivars. The values obtained for $a^{*}$ (red-green component) were significantly higher in the cv. San Andreas strawberries, that is, they were redder in colour. The cv. San Andreas strawberries also showed the highest values for the parameter $b^{*}$ (yellow-green component) as compared to cultivar Monterey, indicating a more yellowish colour (Table 2).

No differences were found amongst the cultivars cultivated in the organic system. However, when comparing the two cultivation systems, the values obtained for the $L^{*}, a^{*}$ and $b^{*}$ parameters of $c v$. Monterey were higher when cultivated in the organic system. For the cultivar
Albion, the value for $\mathrm{a}^{*}$ was higher in the organic system and for the cv. San Andreas no differences were found for colour between the two cultivation systems (Table 2). In a study of strawberries from two cultivation systems, Crecente-Campo et al. (2012) reported that the colour of the organic fruits was darker, less vivid and frequently redder. In another study with eight strawberry cultivars, different levels of the pigments that give colour to the strawberries (anthocyanins) were found between the organic and conventional cultivation systems (CAMARGO et al., 2011). Differences in the colour of strawberries amongst cultivars of the same species are common, and can be influenced by weather conditions and cultural factors (CHITARRA; CHITARRA, 2005).

\subsection{Mineral composition}

The Monterey and San Andreas cultivars from the conventional system showed the highest values for $\mathrm{Ca}$ of 5.27 and $4.87 \mathrm{~g} \mathrm{~kg}^{-1}$, respectively (Table 3). For these cultivars the values for $\mathrm{Ca}$ content did not differ when cultivated in the organic system. The fruits of $\mathrm{cv}$. Albion showed higher levels for $\mathrm{Ca}\left(4.27 \mathrm{~g} \mathrm{~kg}^{-1}\right)$ when cultivated in the organic system, while for cv. Monterey, the $\mathrm{Ca}$ levels were higher when produced in the conventional system $\left(5.27 \mathrm{~g} \mathrm{~kg}^{-1}\right)$. No differences were observed for Mg content amongst the three cultivars when produced in the conventional system. The Monterey and San Andreas cultivars showed the highest values for Mg, with 1.28 and $1.39 \mathrm{~g} \mathrm{~kg}^{-1}$, respectively, when cultivated in the organic system.

The cv. San Andreas showed the highest K content $\left(20.23 \mathrm{~g} \mathrm{~kg}^{-1}\right)$ when grown in the organic system, with no differences between the cultivars Albion and Monterey. The $\mathrm{P}$ content did not differ either amongst the cultivars or between growing systems.

The micronutrients $\mathrm{Cu}$ and $\mathrm{Mg}$ showed no differences amongst the cultivars or between the growing systems (Table 3). No difference was recorded for Fe amongst the cultivars, but when comparing the two growing systems, the Monterey and San Andreas cultivars showed the highest Fe contents, with 122.3 and $128.00 \mathrm{mg} \mathrm{kg}^{-1}$ when

Table 2. Colour parameters for the strawberry cultivars cultivated in the organic $(O)$ and conventional $(C)$ systems.

\begin{tabular}{ccccccc} 
Colour parameters & Cultivation & Albion & Monterey & San Andreas & CV (\%) \\
$L^{*}$ & $\mathrm{C}$ & $27.3 \mathrm{ABa}^{*}$ & $23.4 \mathrm{Bb}$ & $31.9 \mathrm{Aa}$ & 9.64 \\
& $\mathrm{O}$ & $28.1 \mathrm{Aa}$ & $31.3 \mathrm{Aa}$ & $28.7 \mathrm{Aa}$ & 9.32 \\
$a^{*}$ & $\mathrm{C}$ & $24.0 \mathrm{Bb}$ & $22.3 \mathrm{Bb}$ & $30.9 \mathrm{Aa}$ & $29.4 \mathrm{Aa}$ & \\
& $\mathrm{O}$ & $29.4 \mathrm{Aa}$ & $33.3 \mathrm{Aa}$ & $14.4 \mathrm{Aa}$ & 24.26 \\
$b^{*}$ & $\mathrm{C}$ & $12.9 \mathrm{Ab}$ & $10.6 \mathrm{Bb}$ & $18.6 \mathrm{Aa}$ & \\
\hline
\end{tabular}

'Means followed by the same letters, uppercase in the lines and lowercase in the columns, do not differ by Tukey's test at $5 \%$ probability. 
Postharvest quality, antioxidant activity and acceptability of strawberries grown in conventional and organic systems Domingues, A. R. et al.

Table 3. Macronutrient ( $\mathrm{Ca}, \mathrm{Mg}, \mathrm{K}, \mathrm{P})$ and micronutrient $(\mathrm{Cu}, \mathrm{Fe}, \mathrm{Mn})$ contents of the strawberry cultivars in the organic $(\mathrm{O})$ and conventional $(\mathrm{C})$ systems.

\begin{tabular}{|c|c|c|c|c|c|}
\hline Nutrient & Cultivation & Albion & Monterey & San Andreas & CV (\%) \\
\hline $\mathrm{Ca}$ & $\mathrm{C}$ & $3.33 \mathrm{Bb}^{1}$ & $5.27 \mathrm{Aa}$ & $4.87 \mathrm{Aa}$ & 10.95 \\
\hline$\left(g_{k g}{ }^{-1}\right)$ & 0 & $4.27 \mathrm{Aa}$ & $4.33 \mathrm{Ab}$ & $4.77 \mathrm{Aa}$ & \\
\hline$M g$ & C & $1.20 \mathrm{Aa}$ & $1.18 \mathrm{Aa}$ & $1.20 \mathrm{Ab}$ & 5.48 \\
\hline$\left(\mathrm{g} \mathrm{kg}^{-1}\right)$ & 0 & $1.12 \mathrm{Ba}$ & $1.28 \mathrm{Aa}$ & $1.39 \mathrm{Aa}$ & \\
\hline K & C & $18.10 \mathrm{Aa}$ & $18.07 \mathrm{Aa}$ & 17.17 Ab & 6.25 \\
\hline$\left(g_{k g}^{-1}\right)$ & 0 & $16.23 \mathrm{Ba}$ & $14.30 \mathrm{Ba}$ & $20.23 \mathrm{Aa}$ & \\
\hline$P$ & C & $3.31 \mathrm{Aa}$ & $3.94 \mathrm{Aa}$ & $3.64 \mathrm{Aa}$ & 13.70 \\
\hline$\left(\mathrm{g} \mathrm{kg}^{-1}\right)$ & 0 & $3.41 \mathrm{Aa}$ & $3.20 \mathrm{Aa}$ & $3.80 \mathrm{Aa}$ & \\
\hline $\mathrm{Cu}$ & C & $7.33 \mathrm{Aa}$ & 7.23 Aa & $3.70 \mathrm{Aa}$ & 36,15 \\
\hline$\left(\mathrm{mg} \mathrm{kg}^{-1}\right)$ & O & $3.43 \mathrm{Aa}$ & $6.52 \mathrm{Aa}$ & $9.63 \mathrm{Aa}$ & \\
\hline $\mathrm{Fe}$ & C & 110.4 Aa & $94.5 \mathrm{ABb}$ & $80.70 \mathrm{Bb}$ & 12.10 \\
\hline$\left(\mathrm{mg} \mathrm{kg}^{-1}\right)$ & 0 & $117.0 \mathrm{Aa}$ & 122.3 Aa & 128.0 Aa & \\
\hline$M n$ & C & $44.17 \mathrm{Aa}$ & $30.94 \mathrm{Aa}$ & $42.80 \mathrm{Aa}$ & 33.33 \\
\hline$\left(\mathrm{mg} \mathrm{kg}^{-1}\right)$ & 0 & $32.90 \mathrm{Aa}$ & $30.20 \mathrm{Aa}$ & $33.33 \mathrm{Aa}$ & \\
\hline
\end{tabular}

${ }^{1}$ Means followed by the same letters, uppercase in the lines and lowercase in the columns, do not differ by Tukey's test at $5 \%$ probability.

cultivated in the organic system. Similar values were reported by Antunes et al. (2014), who also observed that the mineral content depended on the genotype and weather conditions.

\subsection{Acceptability test}

The questionnaire about consumption frequency and the five preferred fruits of the consumers showed that $40 \%$ of the respondents consumed fruit daily, $41 \%$ often, $13 \%$ sometimes and $6 \%$ occasionally. The five most preferred fruits were banana, strawberry, orange, grape and apple. Regarding the socio-demographic profile, $46 \%$ of the respondents were between $15-24$ years and $51 \%$ were female. Regarding education, $70 \%$ of the respondents were currently completing their higher education, while $21 \%$ had already completed their higher education.

The strawberry fruits of the cultivar Monterey produced in the conventional system obtained the highest values for acceptance (7.51), indicating that the consumers evaluated this cultivar as "liked". The fruits of the cv. San Andreas grown in the organic system received the lowest values for acceptance by the consumers (6.58) meaning that the consumers "liked them slightly" (Table 4).

The cultivar Monterey, cultivated in the conventional system, obtained the highest average for the SS/TA ratio, which may have been a decisive factor for the greater acceptance of the fruits of this cultivar and system, since a previousstudy demonstrated that the characteristic sweetness was the most important factor considered by consumers when purchasing this fruit (BITTENCOURT, 2006). In addition, in a sensory study of the fruit carried
Table 4. Sensory acceptance test for strawberry cultivars in the organic (O) and conventional (C) systems.

\begin{tabular}{clcc} 
& $\begin{array}{c}\text { Cultivation } \\
\text { Albion }\end{array}$ & Monterey & San Andreas \\
\hline Conventional & $7.03 \mathrm{abc}^{1}$ & $7.51 \mathrm{a}$ & $7.39 \mathrm{ab}$ \\
Organic & $6.58 \mathrm{bc}$ & $6.92 \mathrm{bc}$ & $6.58 \mathrm{c}$ \\
\hline
\end{tabular}

${ }^{1}$ Mean values obtained from a nine-point scale; means in the columns followed by the same letter do not differ by Tukey's test at $5 \%$ probability.

out with eight strawberry varieties, there was high correlation between the SS/TA ratio and the attribute of flavour (CAMARGO et al., 2011). Resende et al. (2008) evaluated strawberry cultivar ratios (SS/TA) and consumer acceptability and observed that higher ratios (SS/TA) were associated with better fruit flavour perception.

In the intention to purchase test, the Monterey cultivar produced in the conventional system received $77 \%$ of positive responses (intention to buy the strawberries). In the organic system, the Albion cultivar received the highest percentage of positive responses (69\%). In addition, the fruits of the cultivar San Andreas cultivated in the organic system showed $21 \%$ of negative responses (no intention to buy the strawberries), the least appreciated by the tasters. The intention to purchase reinforced the acceptance results, in which the Monterey cultivar cultivated in the conventional system showed the highest values for acceptance and was the most appreciated, while the cv. San Andreas, cultivated in the organic system, showed the lowest values for acceptance and was the least appreciated (Figure 1). 
Postharvest quality, antioxidant activity and acceptability of strawberries grown in conventional and organic systems Domingues, A. R. et al.

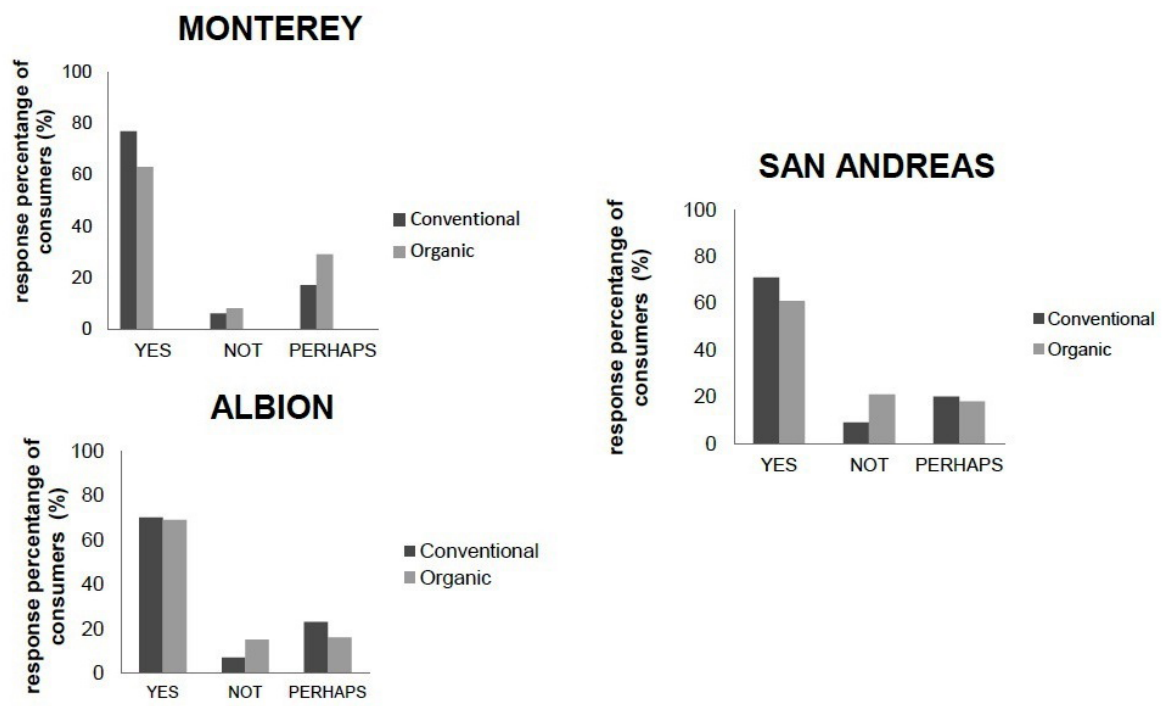

Figure 1. Purchase intention for strawberries of the Albion, Monterey and San Andreas cultivars, cultivated in the conventional and organic systems.

\section{Conclusion}

The strawberry cultivars and cultivation systems have various influences on the total soluble solids, titratable acidity, $\mathrm{pH}, \mathrm{SS} / \mathrm{TA}$ ratio, mineral content and colouring of the strawberries. The fruits of the cultivars Monterey, Albion and San Andreas showed no differences with respect to antioxidant activity, and the cultivation systems did not influence this characteristic either. The Monterey cultivar cultivated in the conventional system showed the highest values for acceptance and percent of intention to purchase amongst the consumers.

\section{References}

AABY, K.; MAZUR, S.; NES, A.; SKREDE, G. Phenolic compounds in strawberry (Fragaria ananassa Duch.) fruits: composition in 27 cultivars and changes during ripening. Food Chemistry, v. 132, n. 1, p. 86-97, 2012. http://dx.doi.org/10.1016/j. foodchem.2011.10.037. PMid:26434267.

ADAY, M. S.; TEMIZAN, R.; BUYUKCAN, M. B.; CANER, C. An innovative technique for extending shelf life of strawberry: ultrasound. Food Science and Technology, v. 52, p. 93-101, 2013.

ALVES, C. Q.; DAVID, J. M.; DAVID, J. P.; BAHIA, M. V.; AGUIAR, R. M. Métodos para determinação de atividade antioxidante in vitro em substratos orgânicos. Química Nova, v. 33, n. 10, p. 22022210, 2010. http://dx. doi.org/10.1590/S0100-40422010001000033.

ANTUNES, M. C.; CUQUEL, F. L.; ZAWADNEAK, M. A. C.; MOGOR, A. F.; RESENDE, J. T. V. Postharvest quality of strawberry produced during two consecutive seasons. Horticultura Brasileira, v. 32, n. 2, p. 168-173, 2014. http://dx.doi.org/10.1590/S010205362014000200008.
ARUOMA, O. I. Methodological characterizations for characterizing potential antioxidant actions of bioactive components in plant foods. Mutation Research, v. 9, n. 20, p. 523-524, 2003.

ÁVILA, M.; TORALLES, R. P.; CANTILLANO, R. F. F.; PERALBA, M. C. R.; PIZZOLATO, T. M. M.; TORALLES, R. P.; CANTILLANO, R. F. F.; PERALBA, M. C. R.; PIZZOLATO, T. M. Influência do sistema de produção e do armazenamento refrigerado nas características físico-químicas e no desenvolvimento de compostos voláteis em morangos. Ciência Rural, v. 42, n. 12, p. 2265-2271, 2012. http://dx.doi.org/10.1590/S0103-84782012005000115.

BITTENCOURT, K. M. V. A. O consumidor responde sobre a aparência e o sabor de diferentes cultivares de morango. Monte Alegre do Sul: APTA, Pólo Regional do Leste Paulista-UPD, 2006.

BRAND-WILLIAMS, W.; CUVELIER, M. E.; BERSET, C. Use of a free radical method to evaluate antioxidant activity. LebensmittelWissenschaft + Technologie, v. 26, n. 1, p. 25-30, 1995. http:// dx.doi.org/10.1016/S0023-6438(95)80008-5.

CAMARGO, L. K. P.; RESENDE, J. T. V.; TOMINAGA, T. T.; KURCHAIDT, S. M.; CAMARGO, C. K.; FIGUEIREDO, A. S. T. Postharvest quality of strawberry fruits produced in organic and conventional systems. Horticultura Brasileira, v. 29, n. 4, p. 577-583, 2011. http://dx.doi.org/10.1590/S0102-05362011000400022.

CANER, C.; ADAY, S. M. Maintaining quality of fresh strawberries through various modified atmosphere packaging. Packaging Technology \& Science, v. 22, n. 2, p. 115-122, 2008. http:// dx.doi.org/10.1002/pts.831.

CEREZO, A. B.; CUEVAS, E.; WINTERHALTER, P.; GARCIAPARRILLA, M. C.; TRONCOSO, A. M. Isolation, identification, and antioxidante activity of anthocyanin compounds in camarosa strawberry. Food Chemistry, v. 123, n. 3, p. 574-582, 2010. http://dx.doi.org/10.1016/j.foodchem.2010.04.073. 
Postharvest quality, antioxidant activity and acceptability of strawberries grown in conventional and organic systems Domingues, A. R. et al.

CHITARRA, M. I. F; CHITARRA, A. B. Pós-colheita de frutas e hortaliças: fisiologia e manuseio. Lavras: UFLA, 2005. 785 p.

CRECENTE-CAMPO, J.; NUNES-DAMACENO, M.; ROMERORODRÍGUEZ, M. A.; VÁZQUEZ-ODÉRIZ, M. L. Color, anthocyanins pigment, ascorbic acid and total phenolic compound determination in organic versus conventional strawberries (Fragaria $x$ ananassa Duch, cv Selva). Journal of Food Composition and Analysis, v. 28, n. 1, p. 23-30, 2012. http://dx.doi.org/10.1016/j.jfca.2012.07.004.

FERNANDES, V. C.; DOMINGUES, V. F.; FREITAS, V.; DELERUEMATOS, C.; MATEUS, N. Strawberries from integrated pest management and organic farming: phenolic composition and antioxidant properties. Food Chemistry, v. 134, n. 4, p. 19261931, 2012. http://dx.doi.org/10.1016/j.foodchem.2012.03.130. PMid:23442640.

FERREIRA, D. F. Programa de análises estatísticas e planejamento de experimentos. Lavras: DEX/UFLA, 2003.

FERREIRA, V. L. P.; ALMEIDA, T. C. A.; PETTINELLI, M. L. C.; DA SILVA, M. A. A.; CHAVES, J. B.; BARBOSA, E. M. Testes discriminativos e afetivos. Campinas: SBCTA, 2000. p. 127.

GUNDUZ, K.; OZDEMIR, E. The effects of genotype and growing conditions on antioxidant capacity, phenolic compounds, organic acid and individual sugars of strawberry. Food Chemistry, v. 155, p. 298-303, 2014. http://dx.doi.org/10.1016/j.foodchem.2014.01.064. PMid:24594188.

HAKALA, M.; LAPVETELAINEN, A.; HUOPALAHTI, R.; KALLIO, H.; TAHVONEN, R. Effects of varieties and cultivation conditions on the composition of strawberries. Journal of Food Composition and Analysis, v. 16, n. 1, p. 67-80, 2003. http://dx.doi.org/10.1016/ S0889-1575(02)00165-5.

INSTITUTO ADOLFO LUTZ - IAL. Normas analíticas: métodos químicos e físicos para a análise de alimentos. 4. ed. São Paulo: Instituto Adolfo Lutz, 2008.

LAIRON, D. Nutritional quality and safety of organic food. A review. Agronomy for Sustainable Development, v. 30, n. 1, p. 33-41, 2010. http://dx.doi.org/10.1051/agro/2009019.

LEE, S. K.; KADER, A. A. Preharvest and postharvest factors influencing vitamin $\mathrm{C}$ content of horticultural crops. Postharvest Biology and Technology, v. 20, n. 3, p. 207-220, 2000. http:// dx.doi.org/10.1016/S0925-5214(00)00133-2.

LUTHRIA, D.; SINGH, A. P.; WILSON, T.; VORSA, N.; BANUELOS, G.; VINYARD, B. T. Influence of conventional and organic agricultural practices on the phenolic content in eggplant pulp: plant-to-plant variation. Food Chemistry, v. 121, n. 2, p. 406-411, 2010. http:// dx.doi.org/10.1016/j.foodchem.2009.12.055.

MALAVOLTA, E. Avaliação do estado nutricional das plantas. 2. ed. Piracicaba: Potafós, 1997.

MALIK, A.; MUKHTAR, H. Prostate cancer prevention through pomegranate fruit. Cell Cycle, v. 5, n. 4, p. 371-373, 2006. http:// dx.doi.org/10.4161/cc.5.4.2486. PMid:16479165.

MANDAVE, P. C.; PAWAR, P. K.; RANJEKAR, P. K.; MANTRI, N.; KUVALEKAR, A. A. Comprehensive evaluation of in vitro antioxidant activity, total phenols and chemical profiles of two commercially important strawberry varieties. Scientia Horticulturae, v. 172, p. 124-134, 2014. http://dx.doi.org/10.1016/j.scienta.2014.03.002.

MEILGAARD, M.; CIVILLE, G. V.; CARR, B. T. Sensory evolution techniques. 3rd ed. London: CRC Press, Inc., 1999. p. 387.

PANICO, A. M.; GARUFI, F.; NITTO, S.; DI MAURO, R.; LONGHITANO, R. C.; MAGRI, G.; CATALFO, A.; SERRENTINO, M. E.; DE GUIDI, G. Antioxidant activity and phenolic content of strawberry genotypes from Fragaria $x$ ananassa. Pharmaceutical Biology, v. 47, n. 3, p. 203-208, 2009. https://doi.org/10.1080/13880200802462337.

PANTELIDIS, G. E.; VASILAKAKIS, M.; MANGANARIS, G. A.; DIAMANTIDIS, G. R. Antioxidant capacity, phenol, anthocyanins and ascorbic acid contents in raspberries, blackberries, red currants, gooseberries and cornelian cherries. Food Chemistry, v. 102, n. 3, p. 777-783, 2007. http://dx.doi.org/10.1016/j.foodchem.2006.06.021.

PINCEMAIL, J.; KEVERS, C.; TABART, J.; DEFRAIGNE, J.; DOMMES, J. O.; DOMMES, J. Cultivars, culture conditions, and harvest time influence phenolic and ascorbic acid contents and antioxidant capacity of strawberry (Fragaria ananassa). Journal of Food Science, v. 77, n. 2, p. 205-210, 2012. http://dx.doi. org/10.1111/j.1750-3841.2011.02539.x. PMid:22251305.

RESENDE, J. T. V.; CAMARGO, L. K. P.; ARGANDOÑA, E. J. S.; MARCHESE, A.; CAMARGO, C. K. Sensory analysis and chemical characterization of strawberry fruits. Horticultura Brasileira, v. 26, n. 3, p. 371-374, 2008. http://dx.doi.org/10.1590/S0102r05362008000300015.

SEN, S.; CHAKRABORTY, R. The role of antioxidants in human health. Washington: American Chemical Society, 2011. Chap. 1, p. 1-37. (Symposium series).

SORRENTI, V.; SALERNO, L.; DI GIACOMO, C.; ACQUAVIVA, R.; SIRACUSA, M. A.; VANELLA, A. Imidazole derivate as antioxidants and selective inhibitors of nNOS. Nitric Oxide, v. 14, n. 1, p. 40-45, 2006. http://dx.doi.org/10.1016/j.niox.2005.09.005. PMid:16275025.

SOUZA, V. R.; PEREIRA, P. A. P.; SILVA, T. L. T.; LIMA, L. C. O.; $\mathrm{PIO}, \mathrm{R}$.; QUEIROZ, F. Determination of the bioactive compounds, antioxidant activity and chemical composition of Brazilian blackberry, red raspberry, strawberry, blueberry and sweet cherry fruits. Food Chemistry, v. 156, p. 362-368, 2014. http://dx.doi.org/10.1016/j. foodchem.2014.01.125. PMid:24629981.

STONE, H.; SIDEL, J. L. Sensory evaluation practices. 3rd ed. London: Academic Press., 2004. p. 408.

WINTER, C. K.; DAVIS, S. F. Organic foods. Journal of Food Science, v. 71, n. 9, p. R117-R124, 2006. http://dx.doi.org/10.1111/j.17503841.2006.00196.x.

YANG, D.; XIE, H.; JIANG, Y.; WEI, X. Phenolics from strawberry CV. Falandi and their antioxidant and a-glucosidase inhibitory activities. Food Chemistry, v. 194, p. 857-863, 2016. http://dx. doi. org/10.1016/j.foodchem.2015.08.091. PMid:26471628.

YOU, Q.; WANG, B.; CHEN, F.; HUANG, Z.; WANG, X.; LUO, P. $G$. Comparison of anthocyanins and phenolics in organically and conventionally grown blueberries in selected cultivars. Food Chemistry, v. 125, n. 1, p. 201-208, 2011. http://dx.doi. org/10.1016/j.foodchem.2010.08.063. 